\title{
iC匡TL
}

International Conference on Research in Education, Teaching and Learning

Paris, France| November 2 -4, 2018

\section{The Economic Situation of Immigrants in the Spanish Educational System}

\author{
Ortiz-Marcos, J.M., Fernández-Leyva, C., and Tomé-Fernández, M. \\ University of Granada
}

\begin{abstract}
Spain has been the second largest European country in migratory movements, but the economic crisis has not been an obstacle to the immigration flow seen in the country. In many Western European countries, newly arrived immigrants and refugees face high levels of unemployment, marginalization, social exclusion, and discrimination in their new societies. The gratuity and support for access to these measures would undoubtedly favor subsequent processes of equitable development in the school and social environment. The limitation of resources for policies focused on the settlement of the immigrant population is being done at a time when their vulnerability is evident. These consequences are due to the time in which we are currently living, characterized by too many sociopolitical uncertainties and turbulences, where the opportunity, access and material goods are distributed in a clearly unjust manner.
\end{abstract}

\section{Introduction}

The immigration has made the number of students in the Spanish educational system, feeding the centers of students in culture, ethnicity and religion, thus $10 \%$ of the total of the Spanish student population is an immigrant, which makes Spain the second largest European country in terms of migratory movements (Torres \& Gadea, 2015). In addition, it must be taken into account that the underlying diversity of immigrant students is influenced by factors of a contextual, geographic, and economic, cultural, social or religious nature, which leaves the different capacities of each of them latent and constitutes an important challenge for education (Pérez \& Sarrate, 2013). Inclusive education is important, which entails the joint learning of all the students that form the educational community, regardless of their origin, personal, social or cultural conditions. It is a personalized education that should be designed for students with a diversity of needs, skills and levels of competence (Taborsky \& Oliveira, 2012).

In relation to this issue, Martínez-Usarralde, et al. (2017) defend that political decisions should facilitate access to education, with greater resources, the expansion and free of charge strategies in educational attention, especially for thosegroups that due to the lack of economic resources cannot afford this type of benefits, giving them greater facilities to access the education system. We must point out that the role of the school is very important to establish the role of immigrants within the target society, so clearly, the structural characteristics of the school's impact on academic performance, focusing on two characteristics: the size of the student body and the school dropout rate. 


\section{iC匡TL}

International Conference on Research in Education, Teaching and Learning

Paris, France| November 2 -4, 2018

Having a large student body and a high dropout rate can be considered negative structural characteristics (Lee et al., 2018). The size of the student body in this case is an ecological characteristic of the structure of the school because different conditions are created for the way in which the students interact with their classmates and teachers and these in turn influence the educational results (Lee \& Lam, 2016). Immigrants choose to live together according to their country of origin, thus creating networks in which to feel accompanied, in addition to helping each other and exchanging information about available jobs, close to the area in which they have decided to create their own net.

\section{Immigration in the Spanish Educational System}

In Spain, the effect that immigration has caused when determining school performance has been overlooked. Clearly, the costs of immigration affect immigrants when deciding whether or not they are selected in the different educational centers of the country. In addition, when people migrate with the whole family, it is likely that the future opportunities of immigrant children will influence the migratory decision of the parents themselves. Therefore, the overall benefits of migration will depend on the motivation and aspirations of the parents. One aspect of the selection of immigrants is, therefore, the participation of parents in the education of their children, which establishes a link between the cost of immigration and the educational performance of immigrant children. When the selection of parents improves the costs of immigration, the educational performance of immigrant children should increase, highlighting in this way the importance of immigrant parents on the educational process of their children (Albornoz et al., 2018).

In Spain, in the last ten years the presence of immigrants has multiplied, reaching almost $10 \%$ of the population enrolled in public schools. The main areas of origin are South America (34.8\%), European Union (28.1\%) and Africa (27.6\%). Specifically, in ESO, immigrant students represent $9.1 \%$ of the school population (Carrasco \& Coronel, 2017). According to Boccagni and Righard (2015), cross-border mobilities and ethnic diversification pose unprecedented challenges to formal and informal arrangements for protection and social welfare. In many Western European countries, newly arrived immigrants and refugees face high levels of unemployment, marginalization, social exclusion, and discrimination in their new societies, and in an attempt to address these challenges, countries have established programs aimed at newly arrived immigrants and refugees, with the aim of facilitating the integration process in the receiving societies (Fernandes, 2015).

From this point, in Spain, is part to start up processes of improvement in the school environment, for the achievement of an inclusive education and quality, defined as a project to combat school failure and against exclusion, that entails a cultural change in schooling, in addition to a political commitment that goes in favor of a more just world (Azorín, 2017). 


\section{iC匡TL}

International Conference on Research in Education, Teaching and Learning

Paris, France| November 2 -4, 2018

Mendo-Lázaro et al. (2016), talk about the need to influence training for a competent social action of Social Educators and by extension of all education professionals, in which generate changes taking advantage of the educational paradigm centered on learning, with higher quality requirements, determining the social competences of university students according to different contexts, so that, improving their social skills, improve those of students from other countries.

The competence of the local language can be the basis of this risk through its effects on the social behavior of children, arguing that ignorance of the language can lead to poor integration, as the low levels of prosociability are associated with the problems of the language. In addition to this, socioeconomic status and lifestyle are influential factors in the health of immigrants, because a low socioeconomic level is associated with worse health (Olsen, et al., 2018).

In the same way, a critical problem that most immigrant students face in Spanish public schools is the persistent low academic performance. Due to this low academic performance among immigrants, a root of the problem is sought. Which has its focus on the disadvantageous conditions encountered by immigrant students when they arrive in Spain, such as the language, in cases in which the students do not come from Latin American countries, a low socioeconomic level, living in less favored neighborhoods and attitudes towards them of native students such as xenophobia, discrimination and stereotypes (Fernández-Reino \& González-Ferrer, 2018).

Beyond factors at the school level, the individual-level relational characteristics of negative school environments can also independently influence the academic outcomes of immigrant adolescents by shaping their perceptions and expectations related to school and education. For example, previous research found that having friends who are not academically oriented and / or lacking academic support adversely affects school performance and therefore facilitates the dropping out of immigrant students (Lee et al., 2018).

The prevalence of negative social relationships (for example, being regularly discriminated against by peers) and the absence of positive social relationships (for example, not having access to academic assistants) could, for example, decrease perceptions of school safety and expectations educational. This is important, since research has shown that perceived school safety and educational expectations function as important conduits between school participation and effort in their academic outcomes (Lee, et al., 2017).

Other problems faced by immigrant students in Spanish educational institutions are the cultural shock that comes from societies with traditions, cultures and religions that are different from those found in Spain, which is why the expected cultural shock must be prevented. With respect to this, Boccagni and Righard (2015) affirm that the social gaps between groups in the population are growing throughout the European welfare state, and both immigrants and ethnic minorities are represented as lagging groups. 




International Conference on Research in Education, Teaching and Learning

Paris, France| November 2 -4, 2018

Immigrants generally have less education, higher poverty rates and tend to be in some of the worst paid and most dangerous occupations (Tseng \& Olsen, 2016).

In Spain, the financial crisis that began in 2008 has worsened this situation by reinforcing hostilities. This crisis has helped to see the immigrant as a threat, who is labeled as a foreigner who comes to take away the work of the Spaniards or to have privileges in the Educational System, which together with an increase in restrictive legislation, makes the Marginalization is seen as something normal (Cappiali, 2016). This marginalization and discrimination, both in employment and in education, causes immigrant families to be involved in economic problems and stress due to acculturation, which may end up affecting the family members and their family unit (FernándezReino \& González-Ferrer, 2018).

There is a complex dichotomy with regard to the creation of social networks in schools, since these school networks are created by immigrants for an improvement in performance or are actually forced to create them due to the discrimination found in the majority of the cases when arriving at the Spanish educational centers? This question is difficult to answer, since native students also create their own networks and friendships and it would be a difficult task to find out for sure (Mendo-Lázaro, et al., 2016).

The arrival in Spain of immigrant populations is generating a greater awareness on the issue of social and educational difference that implies the commitment to incorporate and provide educational services to immigrant students. Thus, some dimensions of multiculturalism have been established, with special emphasis on the different existing forms of exclusion that operate in the management of difference. and of culture through school policies and practices, where educational leaders need to create a culture of mutual respect. Therefore, leaders must become transforming cultural agents who work to create reflective educational institutions and systems (GómezFalcón et al., 2018).

Therefore, multicultural education should be seen as the language that welcomes student differences when they arrive in the classroom. Organizing educational activities by and for diversity involves promoting a culture of a center where the difference of each person is considered wealth and not poverty, be managed as an opportunity and not a problem and contribute to personal and collective development (Carrasco \& Coronel, 2017).

3 The Spanish Educational Resources before the Current Immigration Flow As indicated in the previous section, Spain has been the second largest European country in terms of migratory movements, but the economic crisis has not been an obstacle for the immigration flow to be reduced in the country. Spain is now one of the most important immigration countries in Europe, and despite the influx of immigrants who are beginning to be more controlled with the establishment of restrictions, has faced a steady increase in the number of immigrants, especially in recent years, and Paris, France| November 2 -4, 2018 


\section{iᄃ匡TL}

International Conference on Research in Education, Teaching and Learning

not only the number is growing, but there is also a diversification of origins, and this is reflected in our classrooms (Ledoux et al., 2018).

In this context it is interesting to analyze what has been the impact of the change in the migratory cycle on foreign minors and specifically as this has been manifested in the Spanish classrooms, both the former Organic Law 2/2006, of May 3, of Education as the Organic Law 8/2013, of December 9, for the Improvement of the Educational Quality, at this moment in force, compile the obligation of the different educational administrations to guarantee the schooling of the students that is incorporated to the Spanish educational system.

In which began to establish different educational measures, the most prominent were the language reception rooms that were managed from the different autonomous communities that make up the Spanish state. Next, Table 1 presents the number of immigrant students admitted to the different educational levels in recent years (M.E.C., 2017-2018).

Table 1: Evolution of immigrant students in Spain.

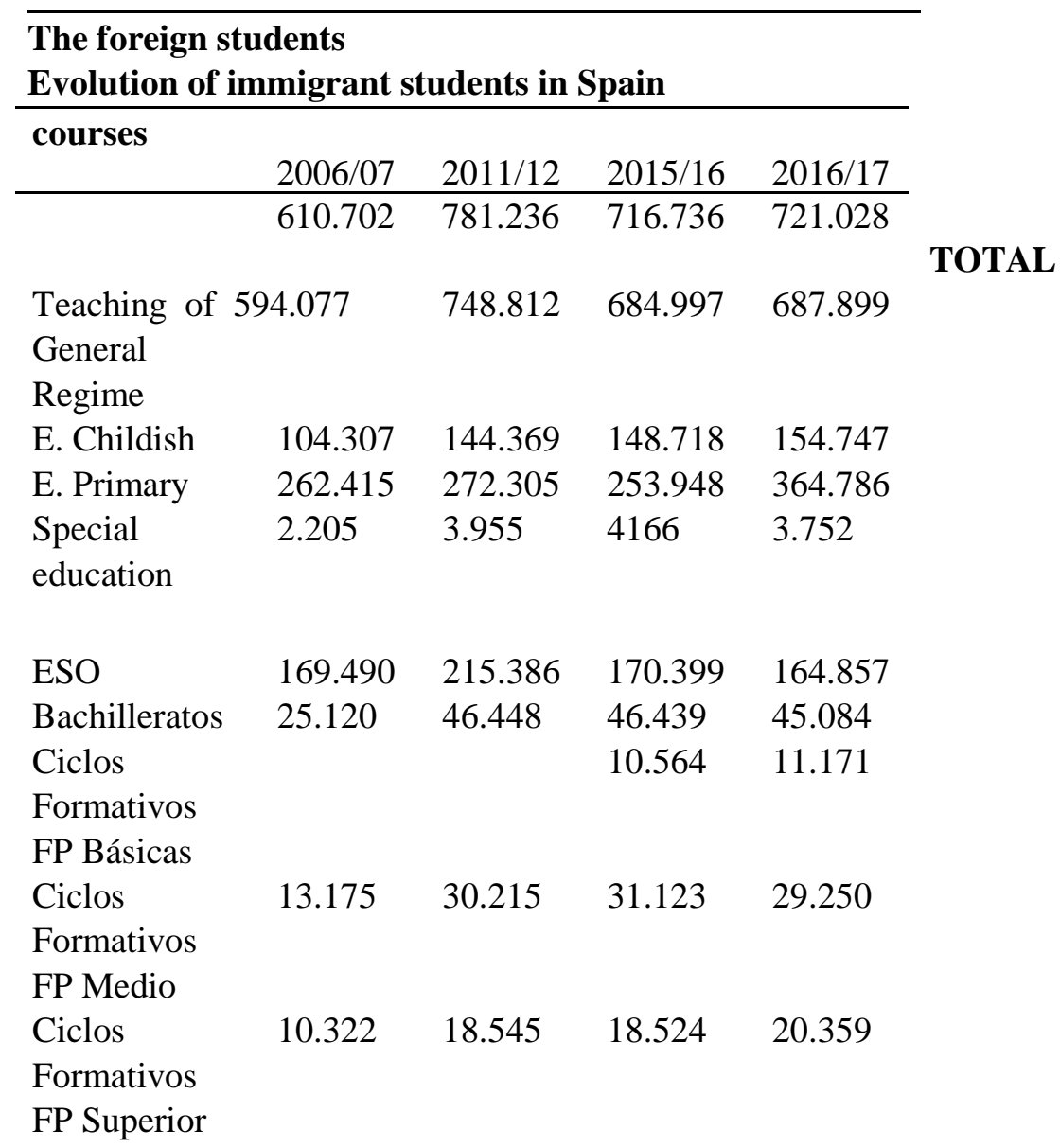




\section{iᄃ匡TL}

International Conference on Research in Education, Teaching and Learning



Paris, France| November 2 -4, 2018

$\begin{array}{lllll}\begin{array}{l}\text { Others } \\ \text { programs }\end{array} & & 1.093 & 2.893 & \text { formative } \\ \text { Teaching } & \text { in } 16.625 & 32.424 & 31.739 & 33.129 \\ \text { Special } & & & & \\ \text { Regime } & & & & \\ \text { Segime }\end{array}$

However, despite the upward evolution in immigrant students, certain recent investigations put the alert in the progressive reduction of educational resources imposed by the limitations of the public budget produced since the beginning of the crisis (Capote \& Nieto, 2017). A reflection of this situation has been the reduction of the teaching staff and the overcrowding of the classrooms, in addition to the scarce resources allocated to care for immigrant students and the difficulty in maintaining intercultural mediation projects initiated (Bouachra et al., 2015; Goenechea, 2015). Since it is not only about putting in place measures of attention to the welcome of the foreign students oriented to the knowledge, but of starting up initiatives that manage the diversity from an intercultural approach that can have a positive impact beyond the classrooms (Capote \& Nieto, 2017).

We have gone from a process of gestation of diversity in Spanish society to a context, especially difficult in recent years. As affirmed by Bueno \& Domingo (2016), the limitation of resources for policies focused on the settlement of the immigrant population (including their school insertion) is being done at a time when their vulnerability as a group is more than evident. With regard to the above, MartínezUsarralde, et al. (2017) argue that political decisions should facilitate access to education, with greater resources, expansion and free of charge strategies in educational care, especially for those groups that due to the lack of economic resources can not afford this type of benefits, giving them greater facilities to access the education system. In Spain, it is intended for each school year, estimated figures based on the available available budgets and, for the current year, based on the initial budgets (MEC, 20172018) where it shows the investments that have been carried out during these last eleven years, and it is perfectly described (see Table 2). 


\section{iCETL}

International Conference on Research in Education, Teaching and Learning

\begin{tabular}{lll}
\hline $\begin{array}{l}\text { Investment in education } \\
\text { Public expenditure on Education }\end{array}$ \\
\hline Years & $\begin{array}{l}\text { Included } \\
\text { Millions }(\boldsymbol{€})\end{array}$ & $\begin{array}{l}\text { Excluded } \\
\text { Millions (€) }\end{array}$ \\
\hline 2007 & $47.266,7$ & $46.790,8$ \\
2008 & $51.716,0$ & $51,122,9$ \\
2009 & $53.895,0$ & $53.374,9$ \\
2010 & $53.099,3$ & $52.557,7$ \\
2011 & $50.631,1$ & $50.343,9$ \\
2012 & $46.476,4$ & $46.215,9$ \\
2013 & $44.74,8$ & $44.491,5$ \\
2014 & $44.846,8$ & $44.519,2$ \\
2015 & $46.620,8$ & $46.281,1$ \\
2016 & $47.654,8$ & $47.235,3$ \\
2017 & $49.418,2$ & $48.934,2$ \\
\hline
\end{tabular}

Looking at the table, you can see how in the different school years the economic investment for schools has been changing, where it is observed how it has been altering and decreasing over the years. Thus, the important budgetary restrictions in this area of $13 \%$ of public investment in education (Mas et al., 2015) have had serious consequences. To cite some examples, since 2009 and despite the increase in enrollment, there are between 28,000 and 32,000 fewer teachers, have worsened the economic and employment conditions of teachers, or has increased the ratio of students per classroom, affecting five times more to the public school than to the private education sector.

But the crisis has also had an impact on families, especially in households with children whose income has been significantly reduced; Therefore, it is estimated that currently one in three children in Spain is at risk of poverty and exclusion (Ayllón, 2015), which entails strong implications in the education system (García-Gómez \& Cabanillas, 2017). Said, in other terms, foreign migrant students are grouped in certain spaces that subtly fall significantly on public education, as opposed to concerted education, which often experiences the minimum alterations in the rate of foreign students in their classrooms (Chamseddine, 2018).

In Spain, students in general are distributed among three types of centers that are public, private and arranged. The figures from the Spanish state (MEC, 2017-2018) 


\section{iᄃ匡TL}

International Conference on Research in Education, Teaching and Learning

show that, taking into account the total number of students, most of them attend public schools, while a much smaller percentage are among the private and private schools, as can be seen in the following Table 3 .

Table 3: Distribution of foreign students by ownership / financing of the center 2017/2018.

\begin{tabular}{lllll}
\hline & \% Total & $\begin{array}{l}\text { \%Public } \\
\text { Centers }\end{array}$ & $\begin{array}{l}\text { \%Concerted } \\
\text { teaching }\end{array}$ & $\begin{array}{l}\text { \%Private } \\
\text { teaching }\end{array}$ \\
\hline Total & 100,0 & 81,1 & 13,6 & 5,4 \\
Andalucía & 100,0 & 84.0 & 7,8 & 8,2 \\
Aragón & 100,0 & 81,3 & 17,0 & 1,7 \\
Asturias & 100,0 & 81,7 & 16,3 & 2,0 \\
Baleares & 100,0 & 76,6 & 16,1 & 7,4 \\
Canarias & 100,0 & 86,1 & 4,0 & 9,9 \\
Cantabria & 100,0 & 72,0 & 26,9 & 1,2 \\
Castilla & 100,0 & 81,5 & 17,3 & 1,2 \\
\multicolumn{1}{c}{ y León } & & & & \\
Castilla-La & 100,0 & 90,7 & 8,7 & 0,7 \\
Mancha & & & & \\
Cataluña & 100,0 & 80,8 & 13,2 & 6,0 \\
Comunitat & 100,0 & 82,7 & 11,3 & 6,0 \\
Valenciana & & & & \\
Extremadura & 100,0 & 91,0 & 8,5 & 0,4 \\
Galicia & 100,0 & 83,9 & 14,3 & 1,9 \\
Madrid & 100,0 & 75,4 & 17,7 & 7,0 \\
Murcia & 100,0 & 88,5 & 9,6 & 1,8 \\
Navarra & 100,0 & 84,1 & 15,4 & 0,5 \\
País Vasco & 100,0 & 70,5 & 28,6 & 0,9 \\
La Rioja & 100,0 & 80,5 & 18,7 & 0,7 \\
Ceuta & 100,0 & 99,0 & 0,9 & 0,1 \\
Melilla & 100,0 & 96,6 & 1,4 & 0,0 \\
\hline
\end{tabular}

In fact, as pointed out by Pyniol Jiménez and Sánchez Montijano (2014), the process of access to citizenship in Spain, besides being one of the most negative in the European Union, is an unequal system, since it gives preference to some collectives over others. Capote \& Nieto (2017) tell us that the debates about the inequality of opportunities in education have revolved around, generally, the socioeconomic disparities of the parents (level of income, training, etc.) where they influence, without doubt, in the decision of parents when choosing a school for children in those countries where they have some room to maneuver to do so and there is a wide range of private or public schools, in addition, in recent years they have reduced the resources allocated to the reception of foreign students, as well as other types of educational projects that promote interculturality within the framework of an inclusive school. For this reason, it is important to also highlight their presence in the Spanish public education system. 


\section{i巨亘TL}

International Conference on Research in Education, Teaching and Learning

Paris, France| November 2 -4, 2018

Regarding the resources allocated in the centers for the attention to immigrant students, García et al. (2015) highlight that during the first decade of the century and coinciding with the important arrival of foreign population, the Spanish educational system developed different initiatives to attend to this new population, in which everyone agrees that those who have dedicated themselves to the attention of new schoolchildren in order to bring them closer to the vehicular language of the school have been the most important. In this way, different types of classrooms have emerged in each Autonomous Community to "welcome" these students and teach them the language of the school.

In Andalusia, for example, they have been called Temporal Classrooms for Linguistic Adaptation (ATAL) and in which each Spanish Autonomous Community is received with a different name (García, et al., 2015). The establishment of these classrooms began in 2004, and represented an important step in the right direction where they were provided with the necessary teaching staff and resources, the teachers involved were highly motivated and the intercultural methodology was employed (Prats et al., 2017).

Frequently, students whose language is very distant from Spanish, especially those of Arabic and Chinese, need to extend this period and it would be convenient for them to have it for longer to reach an acceptable level of linguistic competence in the academic field, but the economic cuts destined to this resource are hindering its effectiveness (Goenechea \& Iglesias, 2016).

This is a difficult task due to the lack of training that the educational system employs in the training of teachers in this resource, and the difficulties of access to administrative information where the first results of these longitudinal investigations with students who have passed through the ATAL (García, et al., 2015) indicate that they have less possibilities of obtaining the Graduate in ESO, regardless of the time they have been in the education system, and that it does not seem, due to the data obtained and analyzed, that the fact of having The state in the ATAL has supposed a substantive improvement in relation to the school success or failure rates, since they are still well below the student body.

This reflects the lack of involvement on the part of the political and economic decisions of the educational system to create new resources that respond to the needs of immigrant students found in Spanish classrooms.

As indicated by Prats et al. (2017) with regard to the distribution of students from immigrant families in schools, it has been quite unequal in Spain. Particularly, the majority of immigrant students are overcrowded (84\%) in public schools, and only $16 \%$ in private or charter schools, as reflected in the official data of the 2017-18 school year (MEC 2017-2018). All these consequences are due to the era in which we are living today, characterized by too many socio-political uncertainties and turbulences, where, in addition, the opportunity, access and material goods are

Paris, France| November 2 -4, 2018 


\section{iᄃ匡TL}

International Conference on Research in Education, Teaching and Learning

distributed in a clearly unfair manner, which turns out to be, although it is rarely understood, a particularly harmful form of violence in a world in which resources exist to provide well-being to all (Borrero \& Blázquez, 2018).

Given this situation, it is necessary to make a reminder to educational administrations with the aim of planning, developing and evaluating efficient actions that favor the incorporation and consolidation of migrant families in the context and the educational community based on criteria of equity and equality. opportunities thus dissociating from the collaborative paths of a conservative and homogeneous nature (Hernández et al., 2016).

\section{Conclusions}

The reality of Spanish schools highlights the need for inclusive education. The immigration present in them is full of life, but also of new difficulties and educational needs, especially in Spanish public education. Thinking differently and creating educational networks suited to these immigrants will make Spain, a migrant country par excellence, become an example of educational integration and development. However, the current realities of their classrooms solve, on average, the educational problems that may arise with the arrival of this type of student body.

In this sense, the economic crisis experienced in the country for almost a decade, means that the necessary resources are not allocated to train schools with professionals and essential materials for inclusive and intercultural education. There is a need for a specialist in foreign languages, intercultural mediators and even a greater number of generalist teachers who can reduce the ratio and thereby increase individualized attention in these classrooms. On the other hand, if the problem is focused on material resources. Spain has overcrowded teachers who do not have specific materials to accommodate the specific educational needs of immigrant students. References

Albornoz, F., Cabrales, A., Calvo, P. \& Hauk, E. (2018). Immigrant children's school performance and immigration costs: Evidence from Spain. Economics Letters, 170, 27-30. doi:

10.1016/j.econlet.2018.05.015

Ayllón, S. (2015). Infancia, pobreza y crisis económica [Childhood, poverty and economic crisis]. Barcelona:

Obra Social "La Caixa".

Azorín, C. (2017). Análisis de instrumentos sobre educación inclusiva y atención a la diversidad. Revista

Complutense de Educación, 28(4), 1043-1060. doi: 10.5209/RCED.51343

Beaman, L. (2012). Social Networks and the Dynamics of Labour Market Outcomes: Evidence from

Refugees Resettled in the U.S. Review of Economic Studies ,79(1), 128-161. doi: 10.1093/restud/rdr017

Boccagni, P. \& Righard, E. (2015) Introduction to the Special Issue: Social Work and Migration in Europe: A

Dialogue Across Boundaries. Journal of Immigrant \& Refugee Studies, 13(3), 221-228, doi:

10.1080/15562948.2015.1059970

Borrero, R. \& Blázquez, F. (2018). La interculturalidad en extremadura: Tareas pendientes para una escuela inclusiva del s. XXI. Educatio Siglo XXI. 36(2), 65-92. doi: 10.6018/j/333121

Bouachra, O., García, F., \& Olmos, A. (2015). Cuando la crisis sirve de excusa. Los recursos escolares para la atención de población de nacionalidad extranjera. En: García, F.; Megías, A. \& Ortega, J. Actas del VIII Congreso sobre Migraciones Internacionales en España. Granada: Instituto Migraciones, Universidad de Granada, 3-22. 


\section{iC医TL}

International Conference on Research in Education, Teaching and Learning

Bueno, X. \& Domingo, A. (2016). La gestión de la interculturalidad en tiempos de crisis: el discurso de los técnicos municipales en Cataluña. Migraciones, 30, 39-65.

Capote, A. \& Nieto, J. (2017). La población extranjera en edad escolar en España: Del boom de la inmigración al cambio en el ciclo migratorio. Revista de geografía Norte Grande. 67, 93-114. doi: $10.4067 / \mathrm{S} 071834022017000200006$

Cappiali, T. (2016). Activism of immigrants in vulnerable conditions and radical-left allies: a case study of

Italy's Struggle of the Crane. Journal of Ethnic and Migration Studies, 42(15), 2508-2527. doi:

10.1080/1369183X.2016.1169917

Carrasco Macías, M. \& Coronel Llamas, J. (2017). Percepciones del profesorado sobre la gestión de la diversidad cultural: Un estudio cualitativo. Educación XX1, 20(1), 75-98, doi: 10.5944/ educXX1.14480

Cayuela, A., Martínez, J. M., Ronda, E., Delclos, G. L., \& Conway, S. (2018). Assessing the influence of working hours on general health by migrant status and family structure: the case of Ecuadorian-,

Colombian-, and Spanish-born workers in Spain. Public Health, 163, 27-34. doi:

10.1016./j.puhe.2018.06.013

Chamseddine, M. (2018). Polarización escolar en España. Retos e implicaciones International Journal of Educational Research and Innovation, 9, 189-205.

Chort, I., Gubert, F., \& Senne, J. (2012). Migrant networks as a basis for social control: remittance incentives among senegalese in France and Italy. Regional Science and Urban Economics, 42(5), 858-874.

Díaz-Rodríguez, D., Hernández-Barrera, V., Jiménez-Trujillo, I., \& Carrasco-Garrido, P. (2018). Factors Associated to Medication Consumption Among the Immigrant Population Residing in Spain. Journal of Immigrant and Minority Health, 20(4), 909-919. doi: 10.1007/s10903-017-0608-2

Fenoll, A., \& Kuehn, Z. (2018). Immigrant networks and remittances: Cheaper together? World Development, $111,225-245$.

Fernandes, A. (2015) (Dis)Empowering new immigrants and refugees through their participation in introduction programs in Sweden, Denmark, and Norway. Journal of Immigrant \& Refugee Studies, 13(3), 245-264, doi:10.1080/15562948.2015.1045054

Fernández-Reino, M. \& González-Ferrer, A. (15 de junio de 2018). Intergenerational relationships among Latino immigrant families in Spain: conflict and emotional intimacy. Journal of Ethnic and Migration Studies, 123. doi: $10.1080 / 1369183 X .2018 .1485205$

García, F., Olmos, A., \& Bouachra, O. (2015). Immigration, crisis and school. Migraciones, 37, 239-263. doi: mig. i37.y 2015.011

García, J., Castilla, J., \& Capellán, L. (2015). ¿Compensar es igualar? Trayectorias de escolares de nacionalidad extranjera en dispositivos "especiales" en el sistema educativo andaluz. En F. García, A.

Megías \& J. Ortega (eds.). Actas del VIII Congreso sobre Migraciones Internacionales en España (pp. S02/13S02/28). Granada: Instituto de Migraciones.

García-Gómez, S., \& Cabanillas, C. (2017). Incidencia de la crisis económica en el alumnado de educación primaria. La perspectiva del profesorado [Incidence of the economic crisis in primary education students. The perspective of the teaching staff]. Revista Complutense de Educación, 28(1), 185-201. doi.org/10.5209/rev_RCED. 2017.v28. n1.49075

Goenechea, C, \& Iglesias, C. (2016). Aportaciones del programa ATAL a los centros educativos desde un punto de vista intercultural. Revista Hachetetepé, 88-104. Goenechea, C, \& Iglesias, C. (2017). Educational resources to cover foreign students'needs in Andalucía. Sinéctica, 48, 1-17.

Goenechea, C. (2015). Evolución de las ATAL en la provincia de Cádiz. ¿Un recurso a extinguir? En: García, F., Megías, A. \& Ortega, J. Actas del VIII Congreso sobre Migraciones Internacionales en España. Granada: Instituto Migraciones, Universidad de Granada, 67-78.

Gómez, I., González, I. \& Coronel, J. M. (2018). Perceptions of secondary school principals on management of cultural diversity in Spain. The challenge of educational leadership. Educational Management Administration \& Leadership, 46(3), 441-456. doi: 10.1177/1741143216670651

Hernández, A., Gomariz, A., Parra, J., \& García, P. (2016). Familia, inmigración y comunicación con el centro escolar: un estudio comparativo. Revista Educación XX1, 19, 127-151.

Ledoux, C., Pilot, E., Diaz, E., \& Kraff. T. (2018). Migrants' access to healthcare services within the european union: A content analysis of policy documents in ireland, portugal and spain. Globalization and health. 14(1), 1-11. doi: 10.1186/s12992-018-0373-6 


\section{iC亘TL}

International Conference on Research in Education, Teaching and Learning

Paris, France| November $2-4,2018$

Lee, M., \& Lam, B. (2016). Academic achievement of socioeconomically-disadvantaged immigrant adolescents: A social capital perspective. International Review of Sociology, 26(1), 144-173.

Lee, M., Kim, Y., \& Madyun, N. (2018). Do relational and structural characteristics of negative school environments independently predict immigrant adolescents' academic achievement? Social Psychology of Education, 21(3), 539-563. doi: 10.1007/s11218-018-9427-0

Lee, M., Lam, B., \& Madyun, N. (2017). Effects of different-race exposure in school and neighborhood on reading achievement of Hmong students in the US. Urban Education, 52(10), 1255-1283.

Ley Orgánica 2/2006, de 3 de mayo, de Educación.

Ley Orgánica 8/2013, de 9 de diciembre, para la Mejora de la Calidad Educativa.

M.E.C. (2018): Datos y cifras. Madrid: Ministerio de Educación, cultura y deporte.

Martínez-Usarralde, M., Lloret-Catalá, C., \& Céspedes, M. (2017). What integration schools of immigrant students do: Indicators for good practices. Pedagogia Social. (29), 39-49. doi: 10. se7179/psri_2017.29.03 Mas, M., Pérez, F., \& Uriel, E. (2015). Capital público en España: Evolución y distribución territorial (19002012). Bilbao: Fundación BBVA.

Mendo-Lázaro, S., León del Barco, B., Felipe-Castaño, E., Polo del Río, M. I. \& Palacios-García, V. (2016). Evaluación de las habilidades sociales de estudiantes de Educación Social. Revista de Psicodidáctica, 21(1), 139.156. doi: 10.1387/RevPsicodidact. 14031

Olsen, R., Roy, S., \& Tseng, H. (2018). The Hispanic health paradox for older Americans: an empirical note. International Journal of Health Economics and Management, 18, 1-19. doi: 10.1007/s10754-018-9241-4 Pinyol, G. y Sánchez, E. (2014). La naturalización en España: una política de claroscuros. En: Arango, J.; Moya, D. \& Oliver, J. (directores). Inmigración y emigración: mitos y realidades. Barcelona, CIDOB, 186-209.

Prats, J., Deusdad, B., \& Cabre, J. (2017). School xenophobia and interethnic relationships among secondary level pupils in spain. Education as Change, 21(1), 95-112. doi: 10.17159/1947-9417/2017/750

Torres, F. \& Gadea, M. (2015). Un proceso de inserción desestabilizado por la crisis. El nuevo ciclo migratorio y las estrategias de los inmigrantes. En: Torres, F. \& Gadea, M. (Coordinadores). Crisis, inmigración y sociedad. Madrid: Talasa Ediciones, 9-35.

Tseng, H. \& Olsen, R. (2016). The U.S. health production function: Evidence from 2001 to 2009. International Journal of Health Economics and Management, 16(1), 51-64. doi: 10.1007/s10754-0159180-2 